\title{
PENGARUH MEDIA PEMBELAJARAN ONLINE TERHADAP HASIL BELAJAR SISWA PADA MASA PANDEMI COVID-19
}

\author{
Ayu Setyoningrum ${ }^{1}$, Fani Rahmasari ${ }^{2}$, Uci Zulfinanda ${ }^{3}$, Prahesti Tirta Safitri ${ }^{4}$ \\ Pendidikan Matematika, FKIP Universitas Muhammadiyah Tangerang \\ ayusetyon50@gmail.com
}

\begin{abstract}
Abstrak
Pasca penyebaran wabah Covid-19 ini berefek pada dunia pendidikan, perubahan sistem pembelajaran secara paksa menjadi kebijakan belajar dirumah secara online atau daring. Hal ini membuat pengajar dituntut untuk dapat menguasai media pembelajaran yang bisa digunakan pada jarak jauh demi mengikuti aturan social distancing yang diberlakukan oleh pemerintah untuk mengurangi angka penyebaran covid-19. Penelitian ini bertujuan untuk mengetahui pengaruh pembelajaran online terhadap hasil belajar matematika siswa. Metode penelitian ini menggunakan metode kuantitatif dengan membandingkan hasil belajar siswa secara online pada siswa di SMA An-Nuqtah. Hasil Pengujian di SMA SMA An-Nuqtah didapatkan bahwa belajar secara online kurang efektif sehingga banyak siswa yang kurang paham dalam materi pembelajaran. Media yang digunakan siswa untuk pembelajaran online yaitu handphone atau laptop dan kendala yang didapatkan pada siswa dalam pembelajaran online adalah kendala kuota dan jaringan internet hal ini mengakibatkan hasil belajar siswa menurun.
\end{abstract}

Kata Kunci: Media Pembelajaran, Pandemi Covid-19, Hasil Belajar Matematika

\begin{abstract}
After the spread of the Covid-19 outbreak had an effect on the world of education, the forced learning system changed to a policy of studying at home online or online. This requires teachers to be able to master learning media that can be used at a distance in order to follow the social distancing rules imposed by the government to reduce the number of spread of covid-19. This study aims to determine the effect of online learning on student mathematics learning outcomes. This research method uses quantitative methods by comparing student learning outcomes online to students at SMA An-Nuqtah. The test results at SMA An-Nuqtah High School found that online learning was less effective so that many students did not understand the learning material. The media used by students for online learning is cellphones or laptops and the obstacles that are found in students in online learning are quota constraints and internet networks, this results in decreased student learning outcomes.
\end{abstract}

Keywords: Learning Media, Covid-19 Pandemic, Mathematics Learning Outcomes 


\section{PENDAHULUAN}

Pasca pandemic Corona Virus Disease(Covid-19) telah menyebar ke 200 negara di dunia termasuk Indonesia, untuk menekan angka penderita Covid-19 dan memutus mata rantai penyebaran virus Corona, pemerintah provinsi dan pemerintah daerah menghasilkan kebijakan seperti isolasi mandiri, social and physical distancing hingga pembatasan sosial berskala besar (PSBB) yang mengharuskan masyarakat untuk beraktivitas bekerja, beribadah dan belajar di rumah. Keputusan yang diambil oleh beberapa negara termasuk Indonesia dengan meliburkan para peserta didik, memindahkan aktivitas proses belajar mengajar di sekolah menjadi di rumah dengan menerapkan kebijakan Work From Home (WFH) membuat resah banyak pihak.

Khususnya dalam dunia pendidikan yaitu dengan meniadakan untuk sementara pembelajaran tatap muka diganti dengan pembelajaran online atau belajar dari rumah masing-masing. Kebijakan ini diberlakukan untuk seluruh jenjang pendidikan, baik formal maupun non-formal, mulai dari pendidikan anak usia dini hingga perguruan tinggi. Layanan pendidikan lain yang bisa dilaksanakan melalui sarana internet yaitu dengan menyediakan materi pembelajaran secara online atau dalam jaringan (daring). Berdasarkan "Surat Edaran Mendikbud No.4 Tahun 2020 Tentang Pelaksanaan Kebijakan dan Pendidikan Dalam Masa Darurat Penyebaran Corona Virus Desease (Covid 19)". Dengan menggunakan sistem pembelajaran secara daring ini, terkadang muncul berbagai masalah yang dihadapi oleh siswa dan guru, seperti materi pelajaran yang belum selesai disampaikan oleh guru kemudian guru mengganti dengan tugas lainnya. Hal tersebut menjadi keluhan bagi siswa karena tugas yang diberikan oleh guru lebih banyak.

Penggunaaan media online seperti google classroom, edmodo, e-learning, atau media online lainnya merupakan salah satu solusi untuk peserta didik mampu mempelajari materi pelajaran dengan baik. Materi yang diberikan dalam bentuk powerpoint, video singkat maupun soal latihan. Namun dalam pelaksanaan pembelajaran daring ini yang menggunakan media aplikasi perlu dilakukan evaluasi untuk didapatkan langkah perbaikan dalam proses pembelajaran untuk mencapai tujuan yang diinginkan. Penggunaan aplikasi dalam pembelajaran tentu saja mempunyai dampak positif dan negatif. Hal ini bisa kita lihat salah satunya dengan cara membandingkan hasil belajar siswa ketika menggunakan google classroom dengan pertemuan tatap muka di kelas.

Media merupakan instrumen yang sangat strategis dalam prespektif pendidikan mendorong untuk ikut menentukan keberhasilan dalam proses belajar mengajar di dunia pendidikan. Dengan keberadaan yang sering ditemukan dapat langsung memberikan semangat tersendiri sesuai dengan bentuk dan tujuan untuk peserta didik. Guru dituntut untuk memanfaatkan media pembelajaran untuk pengajaran selama proses belajar mengajar dilakukan dari rumah. Salah satu proses pembelajaran yang inovatif adalah menggunakan media pembelajaran.

Menurut Sanjaya (2016, hlm. 61), Media pembelajaran adalah segala sesuatu seperti alat, lingkungan dan segala bentuk kegiatan yang dikondisikan untuk menambah pengetahuan, mengubah sikap atau menanamkan keterampilan pada setiap orang yang memanfaatkannya. Arus informasi yang semakin cepat harus diatasi sebaik mungkin oleh guru agar informasi dapat diterima dengan baik oleh siswanya. Sedangkan menurut Kemp dan Dayton (Daryanto, 2013 hlm.6) bahwa media pembelajaran dapat memperjelas penyajian pesan dan informasi sehingga dapat memperlancar dan meningkatkan proses 
dan hasil belajar. Dengan kemajuan teknologi informasi dan komunikasi semakin lama akan semakin berkembang pesat. Hal ini dibuktikan dengan banyaknya inovasi-inovasi yang telah dibuat di dunia ini, seperti di dalam dunia pendidikan. Dengan adanya TIK yang dilengkapi dengan internet maka dapat mendukung proses belajar mengajar dan menyelesaikan masalah pendidikan.

Dalam pelaksanaan pembelajaran dengan media pembelajaran online atau daring menggunakan jasa bantuan perangkat elektronika. Seperti, jasa audio, video, perangkat komputer atau campuran dari ketiganya. Yang memungkinkan tersampainya bahan ajar ke peserta didik dengan menggunakan media internet. Media pembelajaran online atau daring yang banyak digunakan oleh para guru adalah google classroom, dikarnakan pengaplikasiannya sangat mudah digunakan untuk mendukung proses belajar mengajar selama proses belajar mengajar secara daring di rumah. Hal ini sesuai dengan surat edaran Mendikbud Nomor 3 Tahun 2020 tentang Pencegahan Covid-19 pada satuan pendidikan, dan Nomor 36962/MPR.A/HK/2020 tentang Pencegahan Penyebaran Corona Virus Disease (Covid-19) yang mengharuskan proses belajar mengajar secara daring dari rumah demi menghindari terjadinya pertambahan angka penderita Covid-19.

Pandemi adalah penyakit yang menyebar luas misalnya di beberapa benua atau di seluruh dunia. Pendemi Korona 2019 atau lebih dikenal dengan pandemi covid-19 adalah peristiwa menyebarnya penyakit coronavirus 2019 atau corona virus disease 2019 yang ditularkan antara hewan pada manusia. Penyakit ini adalah penyakit jenis baru yang belum pernah ada sebelumnya. Tanda dan gejala umum infeksi COVID-19 antara lain gejala gangguan pernapasan akut seperti sesak napas, batuk, demam,pneumonia,gagal ginjal hingga kematian. Masa inkubasi rata-rata 5 sampai 6 hari hingga terpanjang yaitu 14 hari.

Penyakit virus Corona ini dengan cepat menyebar luas ke seluruh dunia, termasuk di Indonesia. Covid-19 bermula timbul di Wuhan, Cina(Shi, et al., 2020) dan oleh organisasi kesehatan dunia telah diumumkan sebagai pandemic (Sohrabi, et al., 2020). Berbagai negara telah menerapkan isolasi, yaitu pemisahan orang sakit dengan penyakit menular dari orang yang tidak terinfeksi untuk melindungi orang yang tidak terinfeksi(Smith \& Freedman, 2020). Diterapkan pula karantina, yakni pembatasan pergerakan orang yang diduga telah terkena penyakit menular tetapi tidak sakit, baik karena mereka tidak terinfeksi atau karena mereka masih dalam masa inkubasi(Smith \& Freedman, 2020). Karantina mandiri atau isolasi diri dianggap sebagai salah satu cara paling efektif untuk mencegah penyebaran penyakit menular.

Sejak awal masuknya virus Corona ke Indonesia, virus ini terus menyebar cepat hingga mencapai angka 20 ribu jiwa. Untuk mengurangi angka orang yang terinfeksi virus Corona ini dan demi memutus mata rantai penyebaran virus Corona, maka pemerintah menerapkan kebijakan seperti dengan meliburkan aktivitas belajar tatap muka di kelas, aktivitas beribadah di tempat ibadah, dan aktivitas perkantoran atau pekerja, semua aktivitas tersebut dipindahkan kerumah masing-masing.

Hasil belajar terdiri dari dua kata "hasil" dan "belajar". Dalam KBBI hasil memiliki beberapa arti: 1) Sesuatu yang diadakan oleh usaha, 2) pendapatan; perolehan; buah. Sedangkan belajar adalah perubahan tingkah laku atau tanggapan yang disebabkan oleh pengalaman. Abdurrahman menjelaskan secara umum bahwa hasil belajar adalah kemampuan yang diperoleh anak setelah melalui 
kegiatan belajar, menurutnya juga anak-anak yang berhasil dalam belajar ialah berhasil mencapai tujuan-tujuan pembelajaran atau tujuan instruksional.

Hasil belajar sebagai salah satu indikator pencapaian tujuan pembelajaran di kelas tidak terlepas dari faktor-faktor yang mempengaruhi hasil belajar itu sendiri. Sugihartono, dkk. (2007: 76-77), Menyebutkan faktor-faktor yang mempengaruhi hasil belajar, sebagai berikut: a) Faktor internal adalah faktor yang ada dalam diri individu yang sedang belajar. Faktor internal meliputi: faktor jasmaniah dan faktor psikologis. b) Faktor eksternal adalah faktor yang ada di luar individu. Faktor eksternal meliputi: faktor keluarga, faktor sekolah, dan faktor masyarakat. Secara umum dapat didefenisikan bahwa hasil belajar merupakan penilaian diri siswa (Young, Klemz, \& Murphy, 2003), dan perubahan yang dapat diamati, dibuktikan, dan terukur dalam kemampuan atau prestasi yang dialami oleh siswa sebagai hasil dari pengalaman belajar (Nemeth \& Long, 2012).

Dari teori diatas tentang pengertian hasil belajar dapat disimpulkan bahwa hasil belajar adalah kemampuan-kemampuan yang dimiliki peserta didik setelah menerima pengalaman belajarnya, maka hasil belajar yang dimaksud dalam penelitian ini adalah hasil belajar setelah selesai diadakannya sistem belajar mengajar di rumah menggunakan media pembelajaran daring yaitu google classroom dan metode yang dibuktikan dengan hasil berupa nilai akhir peserta didik.

Matematika merupakan ilmu universal yang mendasari perkembangan teknologi, modern, mempunyai peran penting dalam berbgai disiplin, dan mengembangkan daya pikir manusia. Perkembangan pesat di teknologi informasi dan komunikasi dewasa ini juga dilandasi oleh perkembangan matematika di bidang teori bilangan, aljabar, analisis, teori peluang dan matematika diskrit. Untuk menguasai dan menciptakan teknologi di masa depan, diperlukan matematika yang kuat sejak dini.

Belajar matematika pada hakikatnya merupakan proses konstruksi pengetahuan dengan cara mengaitkan suatu konsep matematika ke konsep matematika lainnya baik secara akomodasi maupun asimilasi. Hal tersebut sejalan dengan pendapat Kurniawan (2012:17) yang menyatakan bahwa pembelajaran matematika merupakan proses komunikasi dua arah yang dilakukan guru dan siswa untuk memahami dan mencari hubungan antara konsep dan struktur dalam matematika. Sedangkan menurut Shimada (dalam Suherman dkk, 2011:124) dalam pembelajaran matematika, rangkaian dari pengetahuan, keterampilan, konsep, prinsip, atau aturan diberikan kepada siswa biasanya melalui langkah demi langkah. Rangkaian yang diajarkan tidak saling terpisah, tetapi terintegrasi dengan kemampuan sikap dari setiap siswa sehingga akan terjadi pengorganisasian intelektual yang optimal.

Menurut Subanji (2015:15) dalam proses pembelajaran matematika, sering dijumpai bahwa siswa hanya sekedar meniru prosedur yang sudah dilakukan oleh guru. Bahkan seringkali siswa tidak tahu mengapa harus menggunakan prosedur 
seperti itu. Yang penting bagi siswa adalah sudah menggunakan prosedur yang dicontohkan oleh guru dan memperoleh jawaban yang sesuai dengan kehendak guru. Akibatnya proses pembelajaran tidak mengembangkan berpikir siswa sehingga penalaran tidak terkonstruksi secara baik.

Dalam perkembangan Ilmu Pengetahuan dan Teknologi (IPTEK) Pendidikan matematika merupakan salah satu ilmu pengetahuan yang memiliki peranan penting dan sangat besar perannya dalam mempersiapkan Sumber Daya Manusia (SDM) untuk meningkatkan kualitas sumber daya manusia di dunia. Matematika berperan besar agar mampu menghadapi tantangan era globalisasi. Maka dari itu, siswa harus belajar mengembangkan pikirannya melalui permasalahan matematika sejak dini, agar terlatih secara mandiri dan berkembang untuk kepentingan di masa depan siswa.

\section{METODE}

Metode yang digunakan pada penelitian ini adalah pendekatan kuantitatif. Yang menjadi populasi adalah seluruh siswa kelas VIII SMP IT An-Nuqtah. Data yang digunakan diperoleh dari hasil belajar siswa kelas VIII pada semester ganjil dan pada semester genap. Perbedaannya adalah media pembelajaran yang digunakan. Data pertama merupakan hasil belajar semester ganjil dengan menggunakan sistem tatap muka, sedangkan data kedua merupakan hasil belajar siswa semester genap dengan menggunakan sistem pembelajaran online atau daring. Media pembelajaran daring yang digunakan adalah aplikasi google classroom.

\section{HASIL DAN PEMBAHASAN}

Penggunaan variabel dalam penelitian ini terdiri atas 2 variabel bebas yaitu sistem pembelajaran tatap muka $\left(\mathrm{X}_{1}\right)$ dan sistem online atau daring menggunakan google classroom $\left(\mathrm{X}_{2}\right)$, sedangkan variabel terikatnya yaitu hasil belajar $(\mathrm{Y})$. Penelitian ini dilakukan pengujian dengan 3 asumsi, yaitu uji homogenitas, uji normalitas dan uji -t. Untuk kualifikasi penerimaan dan penolakan digunakan tingkat signifikansi $5 \%$.

Data hasil belajar siswa baik yang menggunakan sistem tatap muka maupun daring atau daring berjumlah 41 siswa. Berikut hasil perbandingan nilai distribusi frekuensi hasil belajar menggunakan media pembelajaran daring dan tatap muka.

Tabel 1. Daftar Distribusi frekuensi dan Nilai Tes Hasil Belajar Siswa Tatap Muka

\begin{tabular}{|c|c|c|c|c|c|c|c|}
\hline KELAS & INTERVAL & f & $\mathrm{Xi}$ & $\mathrm{fi}^{*} \mathrm{xi}$ & $(\mathrm{Xi}-\bar{x})$ & $(\mathrm{Xi}-\bar{x})^{\wedge} 2$ & $f_{i}(x i-\bar{x})^{\wedge} \wedge$ \\
\hline 1 & $71-74$ & 7 & 72.5 & 507.5 & -8.3 & 68.89 & 482.2 \\
\hline 2 & $75-78$ & 9 & 76.5 & 688.5 & -4.3 & 18.49 & 166.4 \\
\hline 3 & $79-82$ & 11 & 80.5 & 885.5 & -0.3 & 0.09 & 0.99 \\
\hline 4 & $82-86$ & 7 & 84.5 & 591.5 & 3.7 & 13.69 & 95.8 \\
\hline 5 & $87-90$ & 1 & 88.5 & 88.5 & 7.7 & 59.29 & 59.3 \\
\hline 6 & $91-94$ & 3 & 92.5 & 277.5 & 11.7 & 136.89 & 410.7 \\
\hline 7 & $95-98$ & 2 & 96.5 & 193 & 15.7 & 246.49 & 493 \\
\hline \multicolumn{2}{|c|}{$\Sigma$} & 40 & 591.5 & 3232 & 25.9 & 543.83 & 1708.4 \\
\hline
\end{tabular}


Berdasarkan nilai rata-rata hasil belajar siswa dengan tatap muka dari tabel 1 adalah diperoleh nilai rata-rata $(\bar{x}=80,8)$, standar deviasi $(S=6,61854)$

Tabel 2. Daftar Distribusi frekuensi dan Nilai Tes Hasil Belajar Siswa Daring

\begin{tabular}{|c|c|c|c|c|c|c|c|}
\hline KELAS & INTERVAL & f & $\mathrm{xi}$ & $\mathrm{fi}^{*} \mathrm{xi}$ & $(\mathrm{Xi}-\bar{x})$ & $(\mathrm{X} \mathrm{i}-\bar{x})^{\wedge} 2$ & 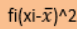 \\
\hline 1 & $70-74$ & 19 & 72 & 1368 & -6 & 36 & 684 \\
\hline 2 & $75-79$ & 8 & 77 & 616 & -1 & 1 & 8 \\
\hline 3 & $80-84$ & 5 & 82 & 410 & 4 & 16 & 80 \\
\hline 4 & $85-89$ & 4 & 87 & 348 & 9 & 81 & 324 \\
\hline 5 & $90-94$ & 2 & 92 & 184 & 14 & 196 & 392 \\
\hline 6 & $95-99$ & 2 & 97 & 194 & 19 & 361 & 722 \\
\hline 7 & $100-104$ & 0 & 102 & 0 & 24 & 576 & 0 \\
\hline \multicolumn{2}{|r|}{$\Sigma$} & 40 & 609 & 3120 & 63 & 1267 & 2210 \\
\hline
\end{tabular}

Berdasarkan nilai rata-rata hasil belajar siswa menggunakan media online aplikasi google classroom adalah diperoleh nilai rata-rata $(\bar{x}=78)$, standar deviasi $(\mathrm{S}=7,52775)$

Berdasarkan perbandingan nilai rata-rata hasil belajar menunjukan bahwa kelas yang melakukan pembelajaran dengan tatap muka memiliki nilai rata-rata sebesar 80,8 dengan standar deviasi 6,61854. Sedangkan kelas yang melakukan pembelajaran dengan media online atau daring memiliki rata-rata 78 dan standar deviasi 7,52775. Ini menunjukan bahwa nilai rata-rata dengan pembelajaran tatap muka memiliki rata-rata lebih tinggi daripada ketika menggunakan pembelajaran dengan media online menggunakan aplikasi goole classroom.

Hal ini sejalan dengan pernyataan Luqman (2020) yang mengatakan bahwa dalam proses belajar-mengajar secara tatap muka ada nilai yang bisa diambil oleh siswa, seperti proses pendewasaan sosial, budaya, etika, dan moral yang hanya bisa didapatkan dengan interaksi sosial di suatu area pendidikan.

Penyebab perbedaan nilai pada pembelajaran tatap muka dengan pembelajaran daring menggunakan google classroom adalah pada penggunaannya harus mepunyai sinyal internet yang stabil serta membutuhkan kuota internet yang cukup besar, bertanya atau berdiskusi menjadi lebih sulit, ketidaksiapan baik guru maupun siswa, bergantung pada kedisiplinan siswa dan belajar daring membuat siswa kurang bersemangat karena kurangnya interaksi dengan pengajar dan kurangnya pengawasan terhadap siswa. Siswa tidak dapat fasilitas akademik dan sosial yang memadai untuk belajar, tapi targetnya tetap.

\section{KESIMPULAN}

Berdasarkan hasil penelitian dan pembahasan yang telah diuraikan maka dapat diambil kesimpulan bahwa hasil belajar siswa secara tatap muka memiliki nilai rata-rata 80,8 dengan standar deviasi 6,61854, sedangkan untuk hasil belajar siswa menggunakan media pembelajaran daring dengan google classroom mempunyai rata-rata 7,8 dan standar deviasi 7,52775. Ini menunjukan bahwa hasil 
belajar matematika siswa secara tatap muka lebih tinggi daripada hasil belajar matematika siswa menggunakan media pembelajaran daring google classroom.

\section{DAFTAR RUJUKAN}

Indah, N. J., Uswatun, D. A., \& Maulana, L. H (2020). Analisis Proses Pembelajaran Matematika Berbasis Daring Menggunakan Aplikasi Google Classroom Pada Masa Pandemi Covid-19, 6 (1), 52.

Rachmat, A., \& Krisnandi, I (2020). Analisis efektivitas Pembelajaran Daring (online) Untuk Siswa SMK Negeri 8 Kota Tangerang pada Saat Pandemi Covid-19.

Desriana, D., Azhar, A., \& Djamaludin, H., (2018). Perbandingan Hasil Belajar Siswa Menggunakan Media Pembelajaran Berbasis Lingkungan Dengan Media Internet Dalam Pembelajaran Asam Basa di MAN Indrapuri.

Sari, C. (2013). Pengaruh Pemanfaatan Media Pembelajaran CD Online Terhadap Minat dan Hasil Belajar Siswa Kelas VII SMP Maria Assumpta Klaten Tahun Ajaran 2012/2013 pada Pokok Bahasan Bilangan Bulat.

Sulistyo, A. (2020). MEMBEDAH KELEMAHAN METODE BELAJAR ONLINE DIBANDINGKAN TATAP MUKA, HTTPS://JEDA.ID/STORIES/MEMBEDAHKELEMAHAN-METODE-BELAJAR-ONLINE-DIBANDINGKAN-TATAP-MUKA-5280

Sundayana, Rostina.(2016). Statistika Penelitian Pendidikan. Bandung: ALFABETA.

Yensy, Nurul Astuty. EFEKTIFITAS PEMbELAJARAN Statistika MatematiKa MELALUI MEDIA WHATSAPP GROUP DITINJAU DARI HASIL BELAJAR MAHASISWA (MASA PANDEMIK COVID 19). JuRNAL PENDIDIKAN MATEMATIKA RAFLESIA 5.2 (2020): 65-74. 